\title{
Description of a new species of the spider genus Syntrechalea (Araneae: Lycosoidea: Trechaleidae) from Colombia
}

\author{
Estevam L. C. da Silva \& Arno A. Lise \\ Laboratório de Aracnologia, Museu de Ciências e Tecnologia, Pontifícia Universidade Católica do Rio Grande do Sul. Avenida \\ Ipiranga 6681, Prédio 40, sala 167, $90619-900$ Porto Alegre, Rio Grande do Sul, Brasil. \\ E-mail: estevamsilva@gmail.com; lisearno@pucrs.br
}

\begin{abstract}
A new species of the spider genus Syntrechalea F.O.P.-Cambridge, 1902 is described and illustrated based on material collected in Loreto Mocagua, Colombia. Representatives of this spider genus exhibit an arboreal foraging behavior and are distinguished from the other genera of Trechaleidae by the flattened carapace, long legs and flexible metatarsi and tarsi. New records on the distribution of Syntrechalea tenuis F.O.P.Cambridge, 1902 in Colombia are presented.

KEY WORDS. Distribution; Neotropical region; spiders; taxonomy.
\end{abstract}

\begin{abstract}
RESUMO. Descrição de uma nova espécie de Syntrechalea (Araneae: Lycosoidea: Trechaleidae) da Colômbia. Uma espécie nova do gênero Syntrechalea F.O.P.-Cambridge, 1902 é descrita e ilustrada, a partir de material coletado em Loreto Mocagua, Colômbia. Os representantes deste gênero apresentam o hábito arbóreo de forragear e são distinguidos dos demais gêneros de Trechaleidae pela carapaça achatada, pernas longas e metatarsos e tarsos flexíveis. Novos registros de distribuição de Syntrechalea tenuis F.O.P.-Cambridge, 1902 na Colômbia são apresentados.
\end{abstract}

PALAVRAS-CHAVE. Aranhas; distribuição; região Neotropical; taxonomia.

Syntrechalea F.O.P.-Cambridge, 1902 was recently revised by CARICO (2008) and comprises eight species, four of them newly described (S. adisi, S. brasilia from Brazil, S. caporiaccoi from Venezuela, S. napoensis from Ecuador, and S. caballero from Paraguay).

The representatives of this spider genus are primarily recognized by the long and slender legs, flattened carapace, and flexible tarsi and metatarsi, character shared with Hesydrus Simon, 1898 , its closely related genus (by the general shape of median apophysis and flexible tarsi and metatarsi). The retrolateral tibial apophysis is bifurcated with the ectal division narrow and the ental division prominent and flattened. The female epigynum is varied but has the middle field distinct and in a posterior position and surrounded by the anterior field. Most of these spiders are arboreal, foraging on the tree trunks in the inundated forests of Northern Brazil (CARICO 2008).

The objective of this work is to describe and illustrate a new species of Syntrechalea from Departamento del Amazonas, Loreto Mocagua in Colombia. New records of the distribution of Syntrechalea tenuis F.O.P.-Cambridge, 1902 in Colombia are presented.

\section{MATERIAL AND METHODS}

The material examined is deposited in Instituto de Ciencias Naturales de la Universidad Nacional de Colombia
(ICN, E. Florez). The nomenclature of the male palpus structures follows CARICO $(1993,2008)$ and Silva et al. (2008). The photograph was obtained with a digital camera connected to the stereomicroscope. All the measurements are in millimeters. The abbreviations related to eyes measurements, including diameter, interdistances and median ocular quadrangle are those routinely used in spider descriptions.

\section{Syntrechalea colombiana sp. nov.}

Figs $1-6$

Type. Male holotype from Loreto Mocagua, Leticia, Departamento del Amazonas, Colombia (350'48"S, 70¹3' 10"W), 15.XI.2001, C. Sandoval leg, deposited in ICN 768.

Etymology. The specific name is a noun and refers to the type locality.

Conditions of holotype. Missing tibia, metatarsus and tarsus of left legs I and II.

Diagnosis. Syntrechalea colombiana is similar to $S$. caporiaccoi by the shape of the ventral division of median apophysis (CARICO, 2008, fig. 24), but can be distinguished by the pointed dorsal division of median apophysis (Fig. 3).

Description. Holotype male. Total length 12.36. Carapace (Fig. 2), 5.05 long, 4.65 wide, yellowish, darker on cephalic area (Fig. 2). Clypeus light brown, darker anteriorly, 0.70 high. Anterior eye row slightly straight, 1.10 wide; posterior 2.29 wide. 


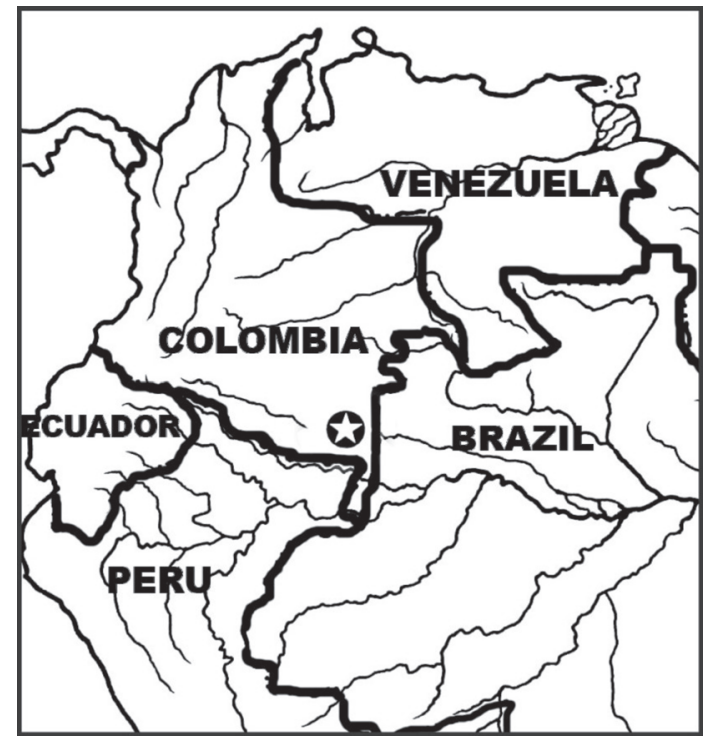

Figure 1 . Type locality of Syntrechalea colombiana sp. nov. in Colombia.

Eye diameters, interdistances, and median ocular quadrangle: AME 0.16, ALE 0.12, PME 0.46, PLE 0.20; AME-AME 0.24, AMEALE 0.12, PME-PME 0.50, PME-PLE 0.46, MOQ, 0.94 long, frontal view, anterior width 0.58 , posterior width 1.12 . Chelicerae light reddish-brown, without lateral carina; promargin and retromargin of fang furrow with three teeth equidistant and equal in size. Sternum bristly, yellowish, darker at margins; 1.99 long, 2.39 wide. Labium brownish, darker at anterior margin, 0.93 long, 0.94 wide. Legs yellowish, with light brown annuli on femora, relative length: IV-I-II-III, leg measurements: I - femur 10.64 /tibia-patella $13.96 /$ metatarsus $10.37 /$ tarsus $6.11 /$ total 41.08; II - 9.57/11.97/9.31/5.98/36.83; III - 7.58/7.98/7.44/5.32/
28.32; IV - 11.57/11.65/12.10/7.31/42.63. Ventral pairs of macrosetae on tibiae: I-6; II-6; III-4; IV-4. Bothrium conspicuous (Fig. 5). Tarsal with three teeth (Fig. 6). Abdomen, 6.65 long, dorsum grayish, bristly, blanched due to conservation (Fig. 2). Venter light brown, scattered setae. Ventral division of median apophysis acute; guide pointed and ventrally curved (Fig. 3). Retrolateral tibial apophysis (RTA) prominent, ectal division acute at apex; ental division lobed (Fig. 4).

Female. Unknown.

Note. The examination of the type of Syntrechalea reimoseri (Caporiacco, 1947) showed some differences in the morphological characters, such as coloration and shape of the abdomen. Also, a juvenile female was found in the same vial as the male described in this paper, but it could not be described because it was an antepenultimate female epigynum and the somatic characters mentioned above are different from $S$. reimoseri. The localities listed in the revision of Syntrechalea F.O.P.-Cambridge, 1902 made by CARICO (2008) are Ecuador, Guyana (female lectotype), Peru, and Brazil. Since there is no material registered from Colombia, the association of this male with the female of $S$. reimoseri is difficult, since in the type series of $S$. reimoseri, there was also included a male that were described as a new species: S. caporiaccoi Carico, 2008.

Distribution. Known only from the type locality (Fig. 1).

Natural history. It is assumed to be arboreal, by its anatomical features which are similar to the other representatives of the genus.

\section{Syntrechalea tenuis F.O. Pickard-Cambridge, 1902}

Syntrechalea tenuis F.O. Pickard-Cambridge, 1902: 314, female holotype from Bugaba, Chiriquí, Panama, Champion leg. (BMNH) (not examined); Roewer, 1954: 139; Bonnet, 1956: 4225; Platnick, 2008. Carico, 2008: 120, figs 1, 8-11.

Syntrechalea porshi Reimoser, 1939: 339 (not examined); Roewer, 1954: 139; Platnick, 2008; Carico, 2008: 120. Syn. nov.

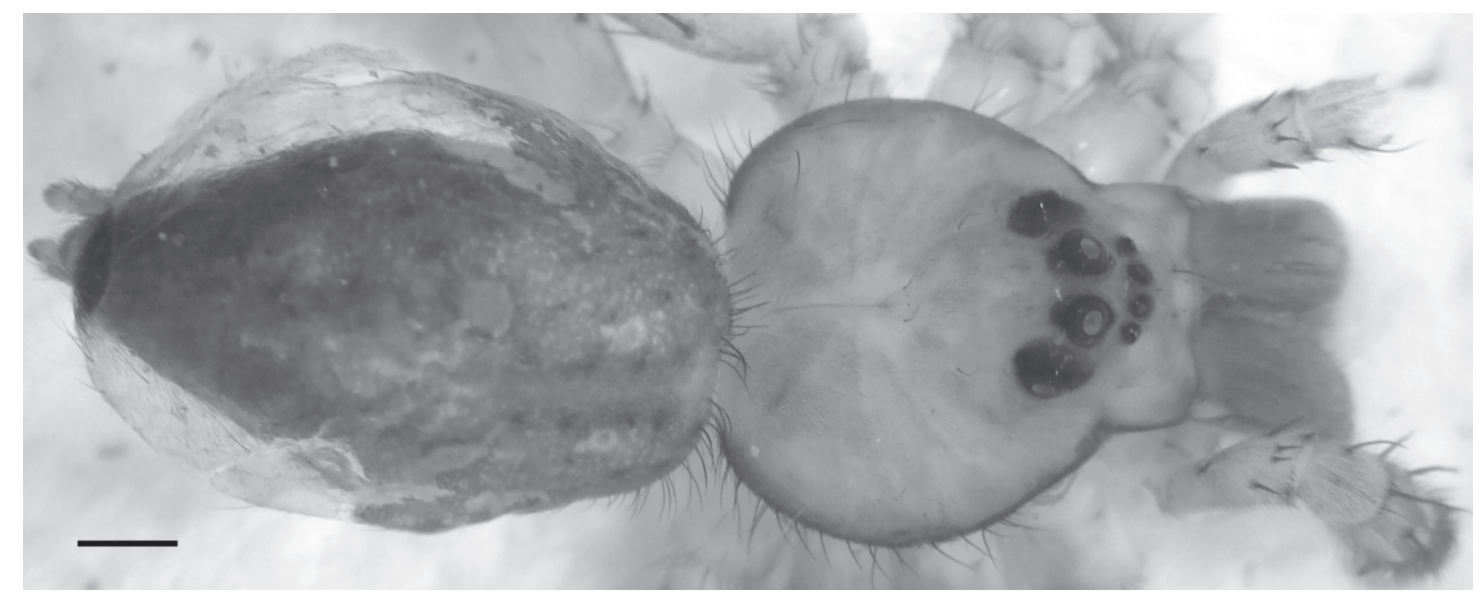

Figure 2. Habitus of Syntrechalea colombiana sp. nov. Scale bar: $1 \mathrm{~mm}$.

Revista Brasileira de Zoologia 25 (3): 495-498, September, 2008 

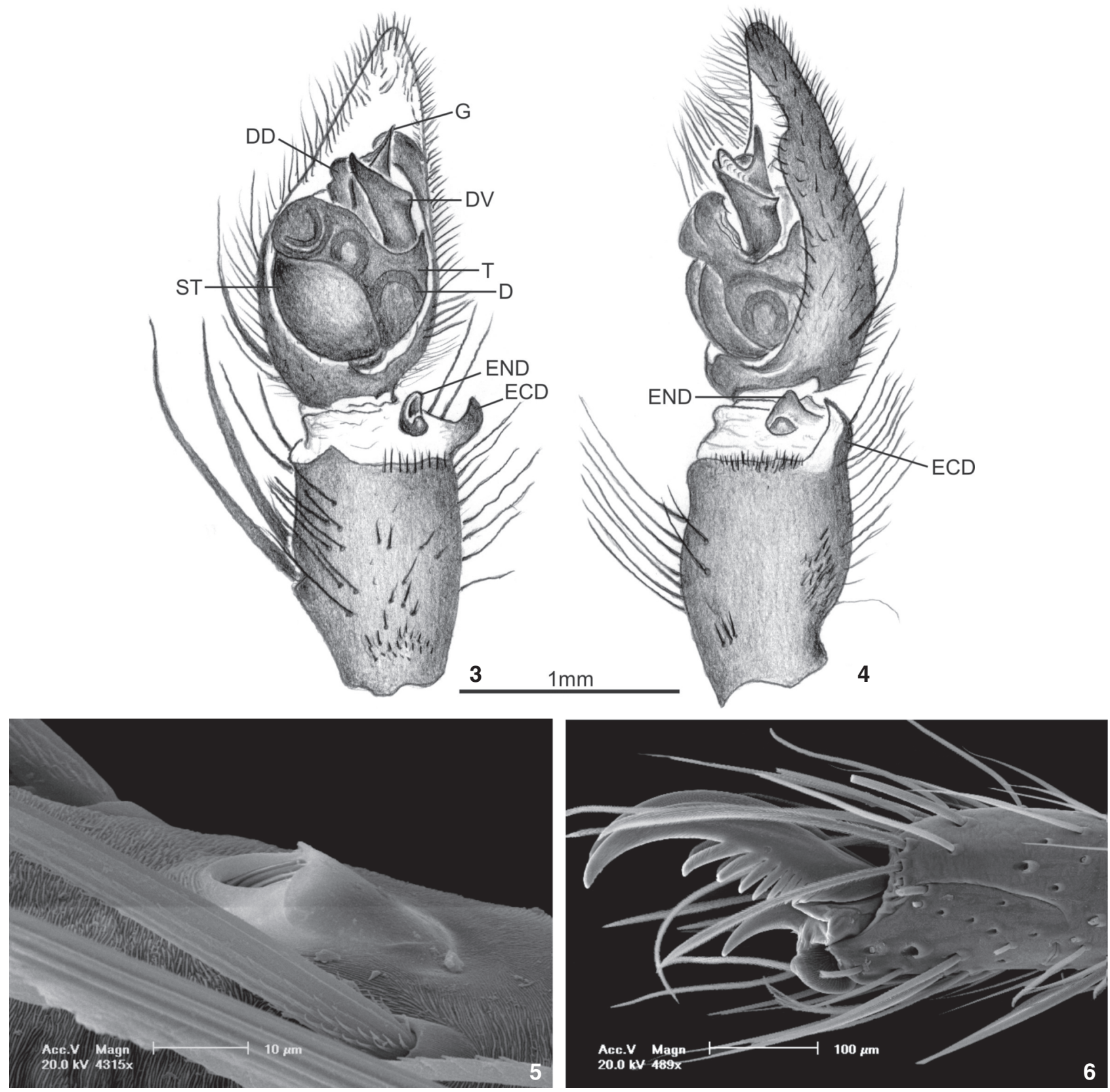

Figures 3-6. Morphological details of Syntrechalea colombiana sp. nov.: (3-4) male palpus: (3) ventral view; (4) retrolateral view; (5) detail of bothrium of right leg IV; (6) tarsal claw of right leg I. (DD) Dorsal division of median apophysis, (ECD) ectal division of RTA, (END) ental division of RTA, (RTA) retrolateral tibial apophysis, (ST) subtegulum, (T) tegulum, (VD) ventral division of median apophysis, (VP) ventrodistal protuberance of male palpal tibia.

Distribution. Mexico, Costa Rica, Panama and Colombia. New records. Colombia, Caqueta: El Paujil $\left(01^{\circ} 33^{\prime} 52^{\prime \prime} \mathrm{N}\right.$; $75^{\circ} 19^{\prime} 55^{\prime \prime} \mathrm{W}, 326 \mathrm{~m}$ ), 1 male, IV.1990, unknown collector (ICN 686); Cundinamarca: Caqueza $\left(04^{\circ} 24^{\prime} 32^{\prime \prime} \mathrm{N}\right.$; $73^{\circ} 53^{\prime} 05^{\prime \prime} \mathrm{W}, 1520$ m), 1 male, 1 female, 04.IV.2002, A. Rodriguez leg. (ICN 1891).

\section{ACKNOWLEDGMENTS}

We wish to thank Dr. Eduardo Florez (ICN) for the loan of the type material and James E. Carico (Lynchburg College) for comments on the manuscript. The technician Maurício Paz

Revista Brasileira de Zoologia 25 (3): 495-498, September, 2008 
França (PUCRS) from the "Centro de Microscopia e Microanálises" (CEMM) for the SEM images. This study was supported by "Conselho Nacional de Desenvolvimento Científico e Tecnológico" (CNPq N 140282/2008-4 for ELCS).

\section{LITERATURE CITED}

Bonnet, P. 1956. Bibliographia araneorum. Analyze méthodique de toute la littérature aranéologique jusqu'en 1939. Toulouse, Les Fréres Douladoure, vol. 2, part 2, p. 919-1926.

Carico, J.E. 1993. Revision of the genus Trechalea Thorell (Araneae, Trechaleidae) with a review of the taxonomy of the Trechaleidae and Pisauridae of the Western Hemisphere. Journal of Arachnology 21 (3): 226-257.

CARICO, J.E. 2008. Revision of the Neotropical arboreal spider genus Syntrechalea (Araneae, Lycosoidea, Trechaleidae). Journal of Arachnology 36 (1): 118-130.
Pickard-Cambridge, F.O. 1902. Arachnida - Araneida and Opiliones. In: F.D. Godman \& O. Salvin (Eds). Biologia CentraliAmericana. London, Zoology, II+610p.

Platnick, N.I. 2008. The World Spider Catalog version 8.5. New York, American Museum of Natural History, available online at: http://research.amnh.org/entomology/spiders/ catalog/html [Access: 30.V.2008].

Reimoser, E. 1939. Wissenschaftliche Ergebnisse der o* sterreichischen biologischen Expedition nach Costa Rica. Die Spinnenfauna. Annalen des Naturhistorischen Museums in Wien 50: 328-386.

Roewer, C.F. 1954. Katalog der Araneae. Bruxelles, Institut Royal des Sciences Naturelles de Belgique, vol. 2a, 923p.

Silva, E.L.C.; A.A. LISE \& J.E. CARICo 2008. Revision of the Neotropical spider genus Enna (Araneae, Lycosoidea, Trechaleidae). Journal of Arachnology 36 (1): 76-110.

Submitted: 30.V.2008; Accepted: 25.VIII.2008.

Editorial responsibility: Antonio D. Brescovit 